\title{
Psychological well-being of the spouses of deployed and non-deployed commissioned officers of Indian Armed Forces: Acomparative study
}

\author{
PRACHI BISHT AND LATA PANDE
}

Received: 08.02.2017; Revised: 06.04.2017; Accepted: 23.04.2017

See end of the paper for authors' affiliations

\section{PRACHI BISHT}

Department of Home Science, D.S.B.

Campus, Kumaon University, NAINITAL

(UTTARAKHAND) INDIA

Email : way2pichi@yahoo.com force personnel face anxiety and stress during the periods of ABSTRACT : Spouse of armed force personnel face anxiety and stress during the periods of
deployment of their husbands to high altitude and other field areas and stress due to the danger of their husband's life as well as managing every task single handedly. Work pressure and separation from the family together makes the condition worse for the soldier thus, cases of anxiety and even suicides among soldiers are also increasing day by day which is also a contributing factor to disturb psychological well being of those spouses whose husbands are deployed away from home. Considering the gravity of the matter present study establishes the differences of various dimensions of psychological well being and overall psychological well being between spouses of deployed and non-deployed commissioned officers of armed forces.100 officers' spouses among which 50 were those who belong to deployed category and 50 belonged to non-deployed category were selected as respondents. Statistical differences were found using students' $\mathrm{T}$ test. The results of the analysis show significant differences in total psychological well-being, life satisfaction and mental health between deployed and non-deployed officers' spouses.

KEY WORDS: Deployed, Non-deployed, Psychological-wellbeing, Stress, Mental health

- HOW TO CITE THIS PAPER : Bisht, Prachi and Pande, Lata (2017). Psychological well-being of the spouses of deployed and non-deployed commissioned officers of Indian Armed Forces: A comparative study. Asian J. Home Sci., 12 (1) : 127-130, DOI: 10.15740/HAS/AJHS/12.1/127-130. 